\title{
The rise of planning in nature conservation and the practitioners' approach to conflicts. The inspiring case of the Northern French Alps nature reserves
}

\author{
Isabelle Arpin \\ Université Grenoble Alpes, Irstea LESSEM, Saint-Martin d'Hères, 38400, France
}

\section{A R T I C L E I N F O}

\section{Keywords:}

Nature conservation

Planning

Conflict

Practitioners

Power imbalances

Northern French alps

\begin{abstract}
A B S T R A C T
This article examines how the rise of planning in conservation influences the conservation practitioners' approach to conflicts in a region where protected areas have limited power. It is based on an analysis of the management plans of ten nature reserves of the Northern French Alps, complemented with interviews with the practitioners involved in elaborating these plans. It shows that the collaborative paradigm, predicated on the idea that deliberation between parties can lead to a shared understanding of the common good, has pervaded conservation planning. Collaborative planning enriches the planners' view of the practices and values at work in the reserves. But it also encourages them to develop conflict avoiding strategies that contribute to maintaining existing power imbalances, which in such regions are often detrimental to conservation goals. Analysing the power relationships at play locally, encouraging the planners' reflexivity, and increasing their agency would help realize the transformative potential of contentious situations.
\end{abstract}

\section{Introduction}

Dietz (2017: 247) recently stated that "a history of US national parks is a history of conflict”. Taking place in areas always already dedicated to other activities, nature conservation at large has been fraught with conflicts since its inception. Conservation practitioners, then, are bound to face contentious situations in the course of their career. Handling conservation conflicts is considered to be particularly difficult and innovative ways of addressing them, through games (Redpath, Keane, \& André, 2018) and art (Peltola, Ratamäki, \& Åkerman, 2018), have recently been discussed. This article investigates under which conditions the making of management plans and the plans themselves can contribute to managing conservation conflicts.

Planning is a relatively recent but rapidly rising activity on the agenda of conservation practitioners and has become one task among many that they must carry out. It has been strongly influenced by the collaborative paradigm and the belief that agreements can be reached through inclusion of interested parties in discussions and planning processes. Taking its inspiration from literature in urban planning, this article focuses on the specific case of nature reserves located in an area - the Northern French Alps- where protected areas have relatively little power. Drawing on observation from the recent development of management plans for ten nature reserves, it explores how planning activities influence how conservation practitioners understand their role in managing conflicts and conflicts themselves.

The article develops as follows. First, it presents the literature about conservation conflicts and conservation planning relevant to this article, as well as the theoretical perspectives that have dominated approaches to conflicts in urban planning. Second, it describes the guidelines for management plans in nature reserves and the specific case of the reserves of the Northern French Alps. Third, it explains how the data were collected. Findings concerning how the planning processes unfolded and how the practitioners view the conflicts in the reserves and their roles in these conflicts are presented in the fourth section. The fifth section discusses the risks of applying the common assumption that consensus must be achieved in regions where protected areas have limited political and economic power ${ }^{1}$. The conclusion underlines the need to pay much more attention to local contexts and power relationships in planning processes, and to enhance the practitioners' agency ${ }^{2}$ and reflexivity regarding the role of planning processes in conflicts.

\footnotetext{
E-mail address: isabelle.arpin@irstea.fr.

${ }^{1}$ Power is understood in the frame of this article as the capacity to control or influence the conducts and actions of others.

${ }^{2}$ Following Eteläpelto et al.'s (2013: 61) subject-centered socio-cultural approach to agency, I will consider that "professional agency is practiced when professional subjects and/or communities exert influence, make choices and take stances that affect their work and/or their professional identities". This agency is always enacted within a specific socio-cultural and material context and is needed especially for developing one's work and work communities, and for taking creative initiatives (Eteläpelto, Vähäsantanen, \& Hökkä, 2013: 62). See their article for a detailed presentation of the various approaches to the notion of agency.
} 
2. Conservation planning, conservation conflicts, and approaches to conflicts in planning theory

\subsection{Conservation planning}

Planning is a well-established activity in various settings such as forest management and urban planning. Forest management plans have a very long history in many countries including France (Boutefeu, 2005). Urban planning has also been shaped by long-standing traditions (Healey, 1997) and has generated much theoretical reflection. In turn, despite important counter-examples such as the creation of the Natura 2000 network in Europe, protected areas have often been created when and where there were opportunities and species have been protected when they were on the verge of extinction: conservation has frequently been undertaken in response to opportunities and/or to emergencies rather than planned. Thus, conservation planning is still in its infancy compared to urban and forest planning.

It has been defined in the early 2000 s as "the process of locating, configuring, implementing, and maintaining areas that are managed to promote the persistence of biodiversity and other natural values" (Pressey, Cabeza, \& Watts, 2007: 584). Margules and Pressey (2000) have defended the need to develop systematic conservation planning to achieve conservation goals. As originally defined, systematic conservation planning largely focused on spatial issues and notably on the location and design of nature reserves. Although systematic conservation planning was originally mainly elaborated in Australia and South Africa, it has become "best practice" in conservation (Grantham, Bode, \& McDonald-Madden, 2010) and a routine task for conservation practitioners (Chevalier, 2010). Management plans in conservation have multiplied considerably over the last two decades and now concern all kinds of natural entities and scales (Chevalier, 2010). A management plan for a protected area is a non-binding document "which sets out the management approach and goals, together with a framework for decision making, to apply in the protected area over a given period of time" (Thomas \& Middleton, 2003: 1).

The collaborative paradigm has largely pervaded planning activities. It exerts a major influence in urban planning (Fox-Rogers \& Murphy, 2016). Its influence is also rising in the making of forest management plans in some countries such as Switzerland and Finland (Cantiani, 2012), while it remains limited in France (Boutefeu, 2005). As presented by Margules and Pressey (2000), conservation planning was initially principally ecology-centered (Ban, Mills, \& Tam, 2013), even though the need to consult key interest groups during the process was underlined. Since then, authors have claimed that conservation planning should include not only ecological but equally social considerations, be infused with social-ecological thinking (Ban et al., 2013) and become a genuine deliberative and participatory process (Reyers, Roux, \& Cowling, 2010). This was notably expected to improve the approach to conservation conflicts.

\subsection{Conservation conflicts}

Conservation conflicts have been defined as "situations that occur when two or more parties with strongly held opinions clash over conservation objectives and when one party is perceived to assert its interests at the expense of another" (Redpath et al., 2013: 100). Many of these conflicts revolve around the establishment and management of protected areas (García-Frapolli, Ayala-Orozco, \& Oliva, 2018).

At least since Simmel (1904), social scientists have underlined the positive role of conflict. In particular, it has been acknowledged as a major factor for change: it is often through conflict that people have been able to transform situations they deemed unsatisfactory. Several benefits of conservation conflicts have been identified, such as increased dialogue and participation in the case of Natura 2000 (Young, Marzano, \& White, 2010: 3984). Cantiani (2012: 73) also points to the positive aspects of conflicts in forest management and notes that these are increasingly seen as opportunities to generate learning and change, rather than as problems to be resolved. However, several authors (De Pourcq, Thomas, \& Arts, 2015; Redpath et al., 2013; Redpath et al., 2018) have recently stressed the destructive aspects of conservation conflicts, stating that they hinder conservation and weigh heavily on the lives of the persons involved, especially in the case of long-term conflicts. They expect these negative aspects to worsen and multiply with the growth of human population and the extension of protected areas. They do not believe that conservation conflicts can be entirely resolved, but they stress the need to better understand their dynamics and find ways of reducing their most damaging impacts. Conservation conflicts, then, are seen as situations to be managed.

\subsection{Perspectives on conflicts in planning theory}

While there is scant literature about the influence of management planning on conflicts in nature conservation, much attention has been given to this subject in urban and land planning. This body of literature is basically characterized by the opposition between two theoretical perspectives that both claim to achieve more democracy (Bond, 2011; Gualini, 2015).

The first perspective is strongly influenced by Habermas's ideal of deliberative rationality. It is premised on the idea that people with diverging interests and views can at least potentially reach mutual understanding and agreement through undistorted and rational deliberation geared toward the search for the truth. According to Habermas, argumentation between people necessarily leads to consensus as long as it can be 'conducted openly enough and continued long enough' (Habermas, 1984: 42). In this perspective, appropriate discursive practices are hoped to effectively reduce conflict. This approach has strongly influenced urban planning in the 1990s and has notably inspired communicative planning (see Healey, 1997). Planning is then seen as a process of 'communicative action' or dialogue, and planners as "facilitators of this dialogue, and hence as a central coordinative figure who creates the 'forums, arenas or courts' in which communication takes place" (Breheny \& Low, 1995).

The second perspective draws on authors (Mouffe, 2005; Rancière, 1995) who have insisted on the essential role of conflicts in democracy. They analyse consensus-building as a pseudo-democratic way of handling conflicts as it would necessarily strengthen those actors who hold a hegemonic position at a given time and always entail some form of exclusion. The goal, then, should not be to overcome conflicts and build consensus among inevitably disagreeing actors but, rather, to make the multiple differences more visible and to use these differences as a resource to enhance democracy. According to Mouffe, what is at stake is the capacity to transform antagonism, i.e. conflict between enemies, into agonism, understood as a relationship between adversaries, "whose ideas we combat, but whose right to defend those ideas is not put into question" (Mouffe, 2000: 102).

Both perspectives have been heavily criticized: the first one for its idealism and its alleged support to the status quo and the neoliberalization of contemporary societies (for a critical presentation of communicative planning, see e.g. Purcell, 2009); the second one for its lack of empirical input about how to achieve pluralist agonism in practice (Özdemir \& Taşan-Kok, 2017). Overall, the first approach has clearly been more influential in planning (Breheny \& Low, 1995; Fox-Rogers \& Murphy, 2016) and most planners think that they need to seek consensus (Özdemir and Taşan-Kok, 2017). Despite the harshness of the debate and the fact that these approaches appear to be "in essence at odds" (Bond, 2011: 171), some authors have sought to combine them. Bond (2011: 180) has suggested introducing insights from communicative planning into Mouffe's pluralist agonism. Also Beaumont and Loopmans (2008) and Gualini (2015) have claimed that Habermas's communicative rationalism and Mouffe's pluralist agonism can and need to be integrated in order to achieve more democratic planning practices. 
As this article will show, these perspectives have influenced the guidelines for writing management plans and the resulting documents to very different extents.

\section{Nature reserves' management plans and their making}

\subsection{Guidelines for management plans in nature reserves}

Management plans for nature reserves became compulsory in France in 1995 (Bioret, 2003). As only half of existing nature reserves had a validated management plan in 2002 (Bioret, 2003), the obligation was reinforced in 2005 and financial sanctions were imposed on the few nature reserves still without a plan (Chevalier, 2010). National guidelines were elaborated that the management plans' authors must follow. The first guidelines were published in 1991 and updated in 1998, 2006 (Bioret, 2003; Réserves Naturelles de France \& Chiffaut, 2006) and 2018. The 2006 and 2018 versions of the guidelines are considered in this article.

According to the 2006 guidelines, the main goal of management plans for nature reserves was to define conservation goals and a five- or ten-year ${ }^{3}$ schedule of operations that could be deemed legitimate because they were based on a thorough and "objective" analysis of the situation of the reserve.

These guidelines did not explicitly encourage planners to focus on conflicts, which were mentioned only twice in 66 pages (Réserves Naturelles de France \& Chiffaut, 2006: 32-33). They merely indicated that the planners should comment on the potential conflicts influencing the reserve. They also stipulated that the negotiation process should be organized by the advisory board of the reserve and they provided planners with some advice about how to present the plan to the actors and go about the negotiation (Réserves Naturelles de France \& Chiffaut, 2006: 62).

New guidelines started to be elaborated in 2009 through a long and complex process involving many actors. Although they had just been published at the time of writing this article, draft versions of these new guidelines had already been used to elaborate the management plans of some nature reserves in the Northern French Alps. The 2018 guidelines (Collectif, 2017) put more emphasis on conflicts than the previous ones (the word is used a dozen times in 58 pages). The goal remains to overcome conflicts, which is claimed to be feasible if conflicts "are managed rather than occulted" (Collectif, 2017: 39). Practitioners are encouraged to involve concerned actors at the very start of the planning process, to address conflicts as soon as they emerge, and to resort to external mediators if needed. These recommendations are in line with international guidelines (see e.g Eurosite, 2004; Thomas \& Middleton, 2003), which all insist on the need to achieve consensus.

\subsection{Nature reserves in an intensive touristic mountain area}

There are currently some 350 nature reserves in France, covering 67.8 million hectares. They are managed by a broad range of institutional bodies (protected areas, environmental NGOs, municipalities, etc.). The status of the person in charge of a reserve and its management, called the conservateur, depends on the type of body managing the reserve. Most conservateurs have a background in ecology or environmental sciences.

I focus here on ten nature reserves located in the Northern French Alps (see Table 1). These reserves differ in ecological conditions and status of the institutional bodies in charge of their management (national parks, regional natural parks, nature conservatories, forest national office). But they share an important common characteristic for this article: they are highly exposed to serious conflicts, because of their

\footnotetext{
${ }^{3}$ Due to the slow evolution of mountain nature reserves, their management plans can be elaborated for ten years, with a mid-term evaluation.
}

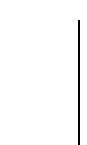

$\sqrt{3}$ 
large size in several cases (e.g. reserve 10, which is the largest nature reserve in mainland France), and of the presence of a range of relatively intensive human activities (winter and summer tourism, sports competitions, scientific research, fishing, hunting as well as berry and mushroom picking in some reserves) within the reserves or in their immediate vicinity. Part of these activities are carried out by economically and politically powerful actors, such as the managers of large ski resorts, the national electricity company (EDF), and many local municipalities that have financial and human resources far in excess of those of the nature reserves. Thus, these reserves strongly contrast with most protected areas where conservation conflicts have been studied (see e.g. Dowie, 2009; García-Frapolli et al., 2018), which makes them interesting places to examine the practitioners' approach to conflicts in their planning activities.

In rare cases, conflicts concern the very existence of the reserve (reserve 9), or its boundaries (reserves 4 and 9). But, in most cases, they concern a broad set of human activities taking place in the reserves: summer and winter tourism; agriculture; hunting; fishing; and berry and mushroom picking in the reserves where they are authorized; etc. Modalities of conducting scientific research in the reserves can also become an issue and generated serious conflicts in one case (reserve 8).

The management plans of these reserves were elaborated following either the 2006 guidelines or a draft version of the 2018 guidelines. All the persons involved in making the plans of the reserves were employed by the institutional body managing the reserves, on a permanent, longterm or short-term basis. They all had a basic or advanced background in ecology and environmental sciences. Although they are not professional planners, they are hereafter designated as "planners".

\section{Data collection}

Whereas much literature about urban planning and conflict has mainly focused on theoretical discussions, some authors (2013, Forester, 2009; Fox-Rogers \& Murphy, 2016; Özdemir \& Taşan-Kok, 2017; Taşan-Kok, Bertolini, \& Oliveira e Costa, 2016) have argued that more attention should be paid to the actual practices and own accounts of planning practitioners facing contentious situations and that there is much to be learned by interviewing planners about their practices and understanding what they do. Forester (2013), in particular, has collected much material about how planning practitioners face conflict and how they understand their role and practices in such situations.

Chevalier (2010) adopts a similar view by analysing the definition of conservation goals in management plans as a practical problem facing the practitioners. This pragmatic approach is in line with Suchman (2007), who departs from a model seeing plans as guiding human action in an essentially straightforward way, and rather focuses on how plans are enacted in the course of situated actions, according to material and social circumstances.

Following these works, I attended to the practices and accounts of the persons involved in the making of the management plans. I collected the management plans of the aforementioned nature reserves and examined how they address potential or actual conflicts. From February to June 2018, I carried out phone or face-to-face interviews with a dozen persons who either wrote the plans or supervised the writing process of these plans. I also interviewed the person responsible for writing the 2018 guidelines at Réserves naturelles de France. Interviews lasted around one hour, except one that lasted nearly two hours and another one half an hour. I invited informants to retrace the elaboration of the management plan(s) they had been responsible for, explain their role in the process, present the main conflicts in the reserve, say if and how the management plan(s) interfered with these conflicts, and express if and how elaborating the plan(s) had changed their view of the reserve, of the other actors, and of conflicts.

I recorded and transcribed the interviews, and stored them on the interview portal of my research institute. In addition, as a member of scientific councils of several alpine protected areas over the past twenty years, I was able to follow several processes of elaborating management plans for nature reserves, and was well aware of the conflicts in the reserves studied. I then went through all the material collected (interviews and management plans, personal notes about the conflicts and planning processes in the reserves), and coded all the excerpts related to the planners' approach to conflicts and their role in these conflicts. I focused on how they attended to conflicts, whether they tended to acknowledge or on the contrary hide or disguise them, and if and how the planning processes had changed their perspectives and practices related to conflicts and their roles in conflict management.

\section{Making management plans in relatively weak and conflict- prone nature reserves}

\subsection{An increasingly outsourced and strictly steered planning process}

Whereas the first management plans were elaborated by the conservateurs in all the nature reserves, the making of the current plans was increasingly entrusted to staff hired on a short term basis or to master students, working under the close supervision of the conservateurs and other persons in charge of managing the reserves. For instance, the managers of reserves 8 and 9 hired a person through one-year contracts to elaborate the management plans of these reserves. In turn, the management plans of reserves 1-7 were elaborated by master students working under the supervision of the reserves' conservateurs during six months. The conservateur of reserve 10 wrote the main part of the plan, with the help of two interns, but eventually resorted to a private consultant to respond to the requirements of the regional scientific council for nature conservation and finalize the document.

When the process was outsourced, a main concern of the permanent staff was to have a completed and good-quality document at the end of the contract and so, the first task was to set up an agenda to finish the work on time. However, the contracts or internships often came to an end before the planning process was entirely over, which was perceived by the plans' authors as frustrating:

"You do a lot of work, you organize a whole set of meetings to integrate the different points of view of the different actors and at the end of the day, you don't even know if all the measures proposed in the plan have been accepted. So, yes, it's really frustrating".

The making of the management plans was strictly steered. As said, the planners had to respect the guidelines, which some found helpful and reassuring:

"Having a framework was really helpful, also to supervise the person we had hired; it was very easy to tell her: here is the framework you must follow."

But others considered that the guidelines were much too precise, leading to a waste of time and energy:

"It was really tough. I found the framework too fixed, too tight, too scientific. There are too many details, it scares people. There should be a simplified version, giving general guidelines."

Moreover, the first steps of the work had to be validated by several bodies (advisory board and scientific council of the reserve, regional scientific council for nature conservation ${ }^{4}$ ) before the planners could move on to the next step. In particular, the regional scientific council for nature conservation played an important role in steering the process:

"They (the members of the regional scientific council for nature conservation) are really strict. Several of them happen to have been

\footnotetext{
${ }^{4}$ Or nature protection national council in the case, absent in my sample, of a first management plan.
} 
key contributors to the elaboration of the (2006) guidelines; they know the guidelines perfectly and they put you back on the right path if you step out of line. You have to make adjustments and complements to have your plan validated."

\subsection{An enlarged view of the reserves and their stakes}

An important input of the planning processes mentioned by the informants was the enlargement of their views of the reserves and their stakes. In all cases, the planners met the local actors or their representatives individually to talk about their activities in relationship with the reserve. However, it is worth noting that scientific activities were treated apart from the other activities. The planners did not always meet the scientists working in the reserves and, when they did, they considered that the scientists' work was somehow naturally aligned with conservation goals. Thus, the planning processes seem to have contributed to the making of "a space of exception for science" (Benson, 2012: 37).

An informant having written several management plans repeatedly expressed her conviction that a collaborative planning process helps conservation be more effective:

"When I started this work, I only saw the natural heritage aspect of the reserves. I gradually realized that this dialogue with the different groups of actors was important and was also part of these reserves, and that I had to take it into consideration. It might help to get better results regarding natural heritage conservation, because if the different actors can hear the different stakes, then they can go in your direction more easily. Goals and conservation actions to be carried out are better implemented if you have a good dialogue."

Elaborating management plans for the reserves enabled most informants to gain a much clearer vision of the complexity of the activities within the reserves and of the plurality of values of the parties. They acknowledged and considered this change in their relationship to the reserves and their users positively, as they had gained a richer and more accurate understanding of the reserves, compared to the narrow naturalist perspective they had at the beginning of the planning processes.

There were no apparent differences in the ways of conducting the process between the plans following the 2006 guidelines and those following the 2018 guidelines. In some cases, measures to be implemented were presented earlier to the actors, but this was because the conflicts were deemed particularly numerous and serious and not because of the new guidelines. The planners were already committed to collaborative planning under the 2006 guidelines, and the 2018 guidelines seem to have simply confirmed an approach that was already well ingrained in practices.

\subsection{Aversion to conflicts and conflict-avoiding strategies}

Aversion to conflicts was a recurring and striking feature of the interviews. While generally not personally involved, informants saw conservation conflicts only and very negatively. They had all heard about serious ongoing conflicts, in their reserves or nearby protected areas, and were very much afraid of them. They explained that conflicts with local actors should be avoided because they made everyday life extremely complicated for nature managers and prevented them from doing "the real work". They saw the search for consensus and the making of compromises as the solution to avoid or solve conflicts. Only one informant held a diverging opinion. While saying that conflicts had exhausted him, to the point that he had recently moved to other functions, he contended that "compromises with other activities must be limited. Normally, finding a compromise between two parties means striking a balance between them. But it can't be the case in a nature reserve. Otherwise, people will demand anything."
In line with their will to avoid conflict, the informants claimed that the main qualities of a planner were being a good listener and "not taking things personally, staying calm when people get annoyed". In addition to such personal and relational skills, I could identify several strategies in the writing of the plans that sought to prevent and avoid conflicts.

One major strategy was to discuss the general conservation goals of the reserves rather than the concrete operations they entail:

"Specific operations can be discussed endlessly and the managers used to go straight to these operations. Things are much easier if you have a long-term goal and operations are defined according to this goal only in a second stage. It's difficult not to agree on goals such as improving water quality. And then the problems, the sources of pollution and what can be done together can be discussed."

Moreover, the management plans tended to minimize conflicts in several ways.

First, they did not really enable an external reader to identify the potential and actual tensions that are articulated in a very euphemistic way, if at all (e.g. the conflict over the existence and the limits of reserve 9, conflicts over pastoral and hunting issues in reserve 10).

Second, the management plans put all issues on the same level by listing a number of problems due to legal and illegal human activities in the reserves. For instance, one list included the use of vehicles on the reserve's tracks (for the refuge located inside the reserve and farming activities), hunting, fishing, summer and winter tourism, presence of off-leash dogs, illegal camping, illegal berry and mushroom picking, illegal skiing (outside authorized itineraries), works due to the management of alpine ski slopes and cross-country ski trails, and water pollution due to cheese production in the summer.

Third, some conflicts were defined as interpersonal conflicts and discarded as irrelevant: "A management plan does not suppress and does not manage human relations". In reserve 8 , the conflict between the farmer and the scientists carrying a long-term research programme on marmots had been interpreted as a problem of human relations that the management plan could not tackle, thus disguising the link between the presence of the research team and the creation of the reserve and the interest of the reserve managers in scientific research.

\subsection{A limited use in conflicts}

All informants stated that management plans were rarely used in conflicts and had little or no influence on them. In reserve 8 , for instance, the planning process did not change anything in the longstanding conflict over the water catchment involving the farmer, the local community and the regional health agency. And it had ambivalent effects on the conflict over scientific activities in the reserve: it did encourage the reserve's managers to elaborate an agreement with the researchers and to regulate their activity, but it did not open up a discussion about the place of scientific research in the reserve.

Informants considered that the sole value of management plans in the context of conflicts was that their content could not be further questioned as it had been submitted and accepted by all and could be recalled to justify positions. Overall, informants saw the management plans either as neutral in terms of conflicts or as a way of neutralizing conflicts. They showed little or no awareness that the planning processes could be a resource and have potential to deal with conflicts in a reflexive and transformative manner:

"The management plans did not generate any of the small or big conflicts there have been and still are in the reserves. I am not sure that they helped solve some of these conflicts either."

\section{Discussion}

The making of management plans can arguably contribute to 
acknowledging conflicts by making the plurality of activities and values interacting with conservation more visible. Yet, the planners do not build on conflicts to open up spaces for discussion about conservation, transform power relations and create "a vibrant 'agonistic' public sphere of contestation where different hegemonic political projects can be confronted" (Mouffe, 2005: 3). Their goal is rather to prevent or avoid conflict. They hope that they will achieve consensus by discussing with actors at an early stage of the management plan elaboration process, following a Habermasian ideal of undistorted communication which, it is expected, will help neutralize power relations. In this section, I discuss the risks of this approach in cases such as that of the Northern French Alps nature reserves, where protected areas have relatively little power and conservation planners have limited agency.

Soliku and Schraml (2018) have established that conservation conflicts are not universal and that their development context must be taken into account. This study confirms the need to consider in what political and socio-economic contexts conservation conflicts unfold but it suggests going further than the distinction between developing and developed countries proposed by Soliku and Schraml (2018). GarcíaFrapolli et al. (2018) state that, most of the time, conflicts in protected areas "involve the rich or powerful against poor people without power within regions, countries and at the multinational level". Yet, in the Northern French Alps, the nature reserves' managers are not the powerful actors in conservation conflicts, but the weak ones. This increases the risks "associated with the assumption that good processes are more likely to lead to good outcomes" (Young, Jordan, \& Searle, 2013: 369).

The power imbalances at play tend to increase the conservation planners' aversion to conflict and attraction of consensus, already fostered by national and international guidelines. More than in less developed regions, they might be tempted to euphemize conflicts, withdraw from conflict issues such as the regulation of tourism activities or water management, and fall back on consensual ones, such as the creation of pedagogical paths or the promotion of food production in the reserves. This phenomenon has been described by Lago Marques (2018) for the Marais poitevin natural regional park, where the park's managers accepted to have a marginal position in the major issues, i.e. water management and road construction, to regain the natural regional park label they had lost in the 1990s. The strategies used to minimize conflicts in the management plans might well contribute to this marginalization risk. As stated by Gualini (2015): 59-60), "The absence or marginality of conflict (in the episodes presented) is anything but the expression of a routine capacity of planning processes to lend voice and representation to competing social claims and to effectively settle them through negotiated agreements. Rather, it appears as an expression of an ambiguous capacity of hiding or disguising conflict by selectively (re)defining potential issues of contention and thus unevenly distributing resources and constraints for mobilization." By presenting all issues on an equal footing, management plans might also lead conservation practitioners to intervene in a similar way in all conflictual situations, which comes down to acting relatively strongly with the weak actors, and relatively weakly with the strong ones.

Downsizing or silencing the conflicts over activities such as winter tourism, hydroelectricity, or science in the reserves do not help to discuss if and under what conditions these activities can be compatible with the reserve's main goals, and to transform nature reserves into places where the place and role of conservation can be debated. As suggested by Purcell (2009): 155), it tends to legitimise decisions and dominant perspectives, which, in regions such as the Northern French Alps where protected areas face powerful actors, are seldom in favour of conservation.

Another important characteristic of the current situation of conservation planners, in the Northern French Alps and elsewhere, is their limited agency. Several authors (Allegra \& Rokem, 2015; Özdemir \& Taşan-Kok, 2017) have shown the importance for urban planners engaged in contentious situations to have strong agency, which notably depends on their personal characteristics. In the nature reserves, too, the personal characteristics (professional status, origin, age, gender, location, behaviour in contentious situations) of the planners undeniably matter, and influence their relationships with other parties. This becomes particularly visible when planners leave and are replaced by newcomers who act otherwise.

But, unlike urban planners and forest managers, conservation practitioners in charge of planning activities have seldom been educated in management planning. As beginners, they are more prone to follow guidelines, all the more that they are required to follow them strictly. Not only are they inexperienced in planning; they also have meagre and dwindling resources and must work under the constraint of predefined and tight schedules, which increasingly leads to the outsourcing of planning activities, often to inexperienced persons such as interns. All these factors do not help to take initiatives, especially when facing influential actors defending their interests.

\section{Conclusion}

This article has examined how conservation planners go about their task and deal with conflicts. It aimed to study if and how the rise of planning in conservation changes their approach to conflicts and their role in managing conflicts. It focuses on a region, the Northern French Alps, where protected areas are disadvantaged by power imbalances, contrary to what happens in many regions globally.

The findings strongly suggest that the collaborative paradigm based on the idea that deliberation between parties can lead to a shared understanding of the common good has been at least as pervasive in conservation planning as in urban planning and forest management. Conservation practitioners engaged in planning activities become more aware of the plurality of uses and values in protected areas and shift from a narrow naturalist perspective to a much broader one, sensitive to the multiplicity of perspectives and stakes. Yet, it seems that the rise of communicative planning leads them to develop a number of strategies to shy away from conflicts; it does not encourage them to harness the transformative potential of contentious situations, but, rather, to maintain existing power relationships and imbalances, as was already stated in urban settings (Purcell, 2009). In the context of the Northern French Alps, where numerous and intensive activities are carried out by powerful actors in and around protected areas, these imbalances are often detrimental to nature conservation. This study suggests, then, that the application of general guidelines encouraging conservation planners to seek consensus bears specific risks in regions where protected areas have limited power: the search for consensus cannot be the solution everywhere, irrespective of local political and socio-economic situations, and the approach to conflicts in conservation planning should rest on a close analysis of the power relationships at play.

At least two additional conditions appear necessary to improve the role of planning activities in the management of conservation conflicts. First, the practitioners involved in these activities should be encouraged to reflect on the transformative potential of conflicts, and on the political consequences of systematically seeking consensus. The creation of a body of literature about the role of conservation planning processes in conflicts, similar to what exists in urban planning, would be very helpful to stimulate their reflexivity. Second, their agency should be fostered; this means having a somewhat flexible approach to guidelines for elaborating management plans. Such guidelines are definitely useful and helpful, especially in a field where planning is still recent, but they might also reduce the practitioners' ability to put their personal characteristics and skills at work. And it certainly means having enough time and resources to conduct the planning process under satisfactory conditions, which is not compatible with dwindling human and financial means.

\section{Acknowledgements}

I sincerely thank all the informants who shared insights about the 
conflicts and the planning processes in the nature reserves. I also thank Taru Peltola and two anonymous reviewers for very helpful comments on an earlier version of this article.

\section{References}

Allegra, M., \& Rokem, J. (2015). Planners amid the storm: Planning and politics in the contested metropolitan area of Jerusalem. In E. Gualini (Ed.). Planning and conflict: critical perspectives on contentious urban developments (pp. 145-163). New York: Taylor and Francis.

Ban, N. C., Mills, M., Tam, J., et al. (2013). A social-ecological approach to conservation planning: Embedding social considerations. Frontiers in Ecology and the Environment, 11, 194-202.

Beaumont, J., \& Loopmans, M. (2008). ) Towards radicalized communicative rationality: Resident involvement and urban democracy in Rotterdam and Antwerp. International Journal of Urban and Regional Research, 32, 95-113.

Benson, E. (2012). Endangered science: The regulation of research by the U.S. Marine mammal protection and endangered species act. Historical Studies in the Natural Sciences, 42, 30-61.

Bioret, F. (2003). L'élaboration des plans de gestion des réserves naturelles, bien plus qu'un simple exercice de style. Le courrier de l'environnement de l'Inra, 48, 71-76.

Bond, S. (2011). Negotiating a' democratic ethos': Moving beyond the agonistic - communicative divide. Planning Theory, 10, 161-186.

Boutefeu, B. (2005). L'aménagement forestier en France : à la recherche d'une gestion durable à travers l'histoire. VertigO, 6.

Breheny, M., \& Low, M. (1995). Editorial. Environment and Planning B, 22, 1-4.

Cantiani, M. G. (2012). Forest planning and public participation: A possible methodological approach. iForest, 5, 72-82.

Chevalier, J. (2010). Définition des objectifs de gestion du patrimoine naturel en France : quel cadre théorique pour quelles modalités?PhD Thesis. France: Université de technologie de Troyes.

Collectif (2017). Guide d'élaboration des plans de gestion des espaces naturels. Coll. Cahiers techniques $n^{\circ} 88 \mathrm{AFB}$.

De Pourcq, K., Thomas, E., Arts, B., et al. (2015). Conflict in protected areas: Who says comanagement does not work? PloS One, 10.

Dietz, T., et al. (2017). Science, values, and conflict in the national parks. In S. R. Beissinger, D. D. Ackerly, \& H. Doremus (Eds.). Science, conservation, and national parks. (pp. 247-274). Chicago: The University of Chicago Press.

Dowie, M. (2009). Conservation refugees. The hundred-year conflict between global conservation and native peoples. Cambridge, London: The MIT Press.

Eteläpelto, A., Vähäsantanen, K., Hökkä, P., et al. (2013). What is agency? Conceptualizing professional agency at work. Educational Research Review, 10, 45-65.

Eurosite (2004). Eurosite management planning toolkit. Complementary guidance. A handbook for practitioners. 35 .

Forester, J. (2009). Dealing with differences. Dramas of mediating public disputes. Oxford: Oxford University Press.

Forester, J. (2013). Planning in the face of conflict. The surprising possibilities of facilitative leadership. Chicago: APA Planners Press.

Fox-Rogers, L., \& Murphy, E. (2016). Self-perceptions of the role of the planner. Environment and Planning B, 43, 74-92.

García-Frapolli, E., Ayala-Orozco, B., Oliva, M., et al. (2018). Different approaches towards the understanding of socio-environmental conflicts in protected areas. Sustainability, 10.

Grantham, H. S., Bode, M., McDonald-Madden, E., et al. (2010). Effective conservation planning requires learning and adaptation. Frontiers in Ecology and the Environment, 8, 431-437.

Gualini, E. (2015). Planning and conflict: Critical perspectives on contentious urban developments. New York: Taylor and Francis.

Habermas, J. (1984). The theory of communicative action. Vol. 1. Reason and the rationalization of society. Trans. T McCarthy. Boston, CA: Beacon Press.

Healey, P. (1997). Collaborative planning. Shaping places in fragmented societies. Houndsmills: Macmillan Press.

Lago Marques, M. (2018). "L'"expérience publique de l'environnement" : une analyse des expérimentations au sein de deux Espaces naturels protégés habités, en France et au Brésil ». PhD thesis in sociologyUniversity of Nanterre373.

Margules, C., \& Pressey, R. L. (2000). Systematic conservation planning. Nature, 405.

Mouffe, C. (2000). The democratic paradox. London: Verso.

Mouffe, C. (2005). On the political. London \& New York: Routledge.

Özdemir, E., \& Taşan-Kok, T. (2017). Planners' role in accommodating citizen disagreement: The case of Dutch urban planning. Urban Studies.

Peltola, T., Ratamäki, O., Åkerman, M., et al. (2018). Missing the peacock-Arts, sciences, creativity, and chronic environmental crisis. Polymath: An Interdisciplinary Arts \& Sciences Journal, 8.

Pressey, R. L., Cabeza, M., Watts, M. E., et al. (2007). Conservation planning in a changing world. Trends in Ecology \& Evolution, 22, 583-592.

Purcell, M. (2009). Resisting neo-liberalization: Communicative planning or counter-hegemonic movements? Planning Theory, 8(2), 140-165.

Rancière, J. (1995). La mésentente. Politique et philosophie. Paris: Galilée.

Redpath, S. M., Young, J., Evely, A., et al. (2013). Understanding and managing conservation conflicts. Trends in Ecology \& Evolution, 28, 100-109.

Redpath, S. M., Keane, A., André, H., et al. (2018). Games as tools to address conservation conflicts. Trends in Ecology \& Evolution, 33, 415-426.

Réserves Naturelles de France, \& Chiffaut, A. (2006). Guide méthodologique des plans de gestion de réserves naturelles. MEED/ATEN, Cahiers Techniques n ${ }^{\circ} 7972$.

Reyers, B., Roux, D. J., Cowling, R. M., et al. (2010). Conservation planning as a transdisciplinary process. Conservation Biology, 24, 957-965.

Simmel, G. (1904). The sociology of conflict. I. The American Journal of Sociology, 9 , $490-525$.

Soliku, O., \& Schraml, U. (2018). Making sense of protected area conflicts and management approaches: A review of causes, contexts and conflict management strategies. Biological Conservation, 222, 136-145.

Suchman, L. A. (2007). Human-machine reconfigurations: Plans and situated actions. New York: Cambridge University Press.

Taşan-Kok, T., Bertolini, L., Oliveira e Costa, S., et al. (2016). "Float like a butterfly, sting like a bee": giving voice to planning practitioners. Planning Theory \& Practice, 17, $621-651$.

Thomas, L., \& Middleton, J. (2003). Guidelines for management planning of protected areas. Switzerland and Cambridge, UK: IUCN Gland Ix +79 pp.

Young, J. C., Marzano, M., White, R. M., et al. (2010). The emergence of biodiversity conflicts from biodiversity impacts: Characteristics and management strategies. Biodiversity and Conservation, 19, 3973-3990.

Young, J. C., Jordan, A., Searle, K. R., et al. (2013). Does stakeholder involvement really benefit biodiversity conservation? Biological Conservation, 158, 359-370. 